\title{
Souvenir Inscriptions as a Text for Teaching Punctuation Marks in ESL Situation: a Teacher's Innovation
}

\author{
Faleke Victoria Ogunnike \\ Federal University Dutsin-Ma, \\ Faculty of Arts, Management and Social Sciences \\ Department of Language and Communication Studies \\ Katsina State, Nigeria.
}

\begin{abstract}
Twenty students were randomly sampled from junior secondary one (JSS1) from June -September 2013 in a community called Dutsin-Ma Katsina state Nigeria to ascertain their level of proficiency in some specific aspects of the English language. The finding revealed that the students after spending six years in primary school were found deficient in the learning of the language this was attributed to lack of text books, unavailability of teaching aids, lack of ICT centers in most schools and lack of qualified English language teachers. The scheme to teach the core aspects of the language was drawn. Understanding the use of "punctuation marks" was one of the topics, each student was assigned to bring two each of inscribed souvenirs from home. The inscribed souvenirs were used as text to teach punctuation marks. This improvisation is an effective innovation which enabled students to have an apt comprehension of the topic, and a cheap way of teaching in a developing country.
\end{abstract}

\section{Introduction}

ESL means English as a second language. It is the use of English by speakers with different native language. English as a language has great and reach influence. Teaching English as a second language is a herculean task. There are some factors that are militating against the teaching and the learning of English language in some developing countries that are having serious effect on education, some are: political instability, government policies, corruption, religious crisis, poverty etc. The English language teacher needs to be innovative to be able to overcome them in order to effectively achieve his/her aim. Following the $47^{\text {th }}$ International Association of Teachers of English as a Foreign Language (IATEFL) in Liverpool, in Susan Barduhn's keynote address, that "if English were a drug, expatriate teacher would be the drug dealers..." In the course of expatiating her points, asks a rhetorical question "is a dealer an exploiter of the drug? What is the drug here? Is it language? in order not to leave these questions as rhetorical, I affirm that English language is the drug and I am the drug dealer [1]. To achieve this, I took an initiative and embarked on this voluntary project called PROjectenglish. The main aim is to use what is available to me as a teacher to teach English language from the grass root. The project started mid 2013 to help the schools in community the where I work.

\section{The role of English language in Nigeria.}

Nigeria is an Anglophone country, found in the Sub-Saharan region of West Africa. English language plays a multiple role in Nigeria. It is a Lingua-Franca, official and second language. It is virtually the language of everything: language of education, religion, medicine, advertisement, Business, judiciary, politics, media etc. It is a prerequisite to furthering ones educational carrier into all higher institutions [2]. Nigeria is a multilingual nation; it has more than 400 languages and dialects. Amongst these languages only three have been adopted as official languages, they are Hausa Yoruba, and Igbo; and out of these three English take preeminence.

This means that proficiency in the language has a great economic value and lack of it will lead no one anywhere, so a denial in the proficiency of English language is a great denial to ones progress. In most developing countries the rural areas have been denied of social amenities and have made them to be sparsely populated so much so that no qualified English teacher wants to go to such places to work. This has made most students in the rural areas to be deficient in the learning of the language. This seems to be the situation that most students in the rural areas found themselves.

Aside this, most countries in the world are talking about students autonomy which is learner centered 
which enables learners to use ICT (Information Communication Technology) and other technological device that enhanced learning, are not readily available to most learners in most developing countries. In those countries where they are, they are not enough to cater for their needs, some are not functioning while those that are functioning are obsolete. Other factors are:

1. Epileptic power supply (the cost of generating electricity through industrial generator is very high)

2. Unqualified computer programmers

3. Low level of computer literacy on the part of teachers and learners

4. Government policies

5. Religion

6. The sacredness attached to the handling of computer gadgets

In spite of all these challenges, the English language teacher needs to see him/her self as a drug dealer and be efficient in distributing the 'drug'-English language to the clients to be self reliance in the community where they would find themselves; as affirms by Wedell that “... what is expected of an effective English teacher in a particular context is through looking at what curriculum documents expect learners of English to achieve" [3]. Part of the curriculum planned to teach the students for the project was 'punctuation' which is part of what the language curriculum expect learners to know.

\section{How souvenir is used by Nigerians.}

One weapon the English teacher in the developing country needs is to be 'effective'. It is his/her ability to be innovative through improvisation. This means using what is available to you at present to achieve your aims and objectives without waiting for the 'rainy day' waiting for the rainy day could be an endless one which wastes time and potentials. Effectiveness is all encompassing, it also means being at alert; thoughtful and resourceful. I used souvenirs to teach punctuation marks in a community where there was no availability of text book and teaching aids. It is the cheapest way of teaching and learning, this corroborates with Olawale that "the English teacher needs appropriate skills needed by adult learners of English to make them functional users of the language" [4].

\section{What are Punctuation Marks?}

Punctuation marks are aspect of language that is minute yet very important. Drawing an illustration from King “...a warrior in ancient Greece who, on the eve of leaving for a war, consulted the oracle at Delphi [5]. 'Thou shalt go thou shalt return never by war shalt thou perish;" he was told. The over worked oracle spoke without pause, so the warrior naturally assumed that he meant. "Thou shalt go, thou shalt return, never by war shalt thou perish" He departed with confidence. Unfortunately he was killed in the first battle, never realizing that what the oracle really meant were "thou shalt go; thou shalt return never, by war shalt thou perish". One therefore assumes that there had been very many verbal (spoken) and non verbal (written) conversations that had been misunderstood as a result of improper use of punctuation marks.

According to Babalola, punctuation is a series of marks inserted to mark words one from another either to show their grammatical relationship or to give emphasis to them" [6]. In the same way King says punctuation is "a system capable of conveying force, information, urgency, tension, doubt, rhythm and passion, while never abandoning its duty to consistency and clarity of meaning [5].

The stream of speech could be modified by the various kinds of prosodic devices made to show differentiations which help to communicate the grammatical and other distinctions in the language we speak. The types are: full stop, hyphen, parentheses, comma, colon, semi-colon, dash, ellipsis, question mark, exclamation mark, apostrophe, these are frequently used in writing and felt in connected speeches. The infrequently used ones are: obelisk, caret, and asterisk, (but in souvenir writing asterisk is used often) all these have their symbols that are universally accepted in writing.

\section{The study area.}

There are six geo-political zones in Nigeria namely: south-south, south-east, south-west, northwest, north-east, north-central, Dutsin-Ma as a community is found in the North-West zone in Katsina State, Nigeria. Dutsin-Ma became a local government in 1976, with an area of $527 \mathrm{~km}^{2}$ and a population of 169,671 at the 2006 census [7]. The inhabitants of the people in the local government are predominantly Hausa and Fulani by tribe. Their main occupation is farming and animal rearing. There are only two primary schools, two secondary schools, a state college of education (teacher training) and a Federal University. 


\section{Literature Review.}

Innovation is the spark of insight that leads a scientist or inventor to investigate an issue or phenomenon. That insight is usually shaped by an observation of new idea [9]. Using souvenirs to teach some aspect of English language in a developing country is part teacher's innovation.

The souvenir inscription used in teaching the punctuation is linguistically perceived in this investigation as a text. What than is a text? The word "text" comes from the Latin word 'texere' meaning to weave. Most definitions place "text" as a linguistic structure woven out of word or signs, this means that to call something a text implies that the words, phrases, lines or sentences of which it consist have not been arranged this way by chance, but have been produced by a person and with certain kind of intentions [10]. It therefore contains meaning which is open to interpretation.

Text is extremely significant in communication because people communicate not by means of individual words or fragments of sentence in language, but by means of texts. Crystal and Davy also identify such devices as graphology with its features as: spelling, capitalization, paragraphing, italization, abbreviations, spatial organization, punctuation marks, colours and special symbols (especially logograms) [11]. These devices are evident in the language of souvenir the focus of this paper.

The ESL teacher needs to be innovative enough to work within his/her community to see how the language in question is used by the user and at the same time weaving it into a fine fabric that could at the same time be used to meet their needs. Goldstein emphasized on the importance of using visual image and text to teach composition in the class room stressing that the two should work alongside one another or on equal footing and that one way to explore the relationship between image and text is to look at how both are arranged within an overall composition [12].

Widdowson suggests that language teacher should attempt to associate the language they are teaching with situations outside the classroom, to what frequently refer to as the real world of the family, holidays, sports pastimes and so on...", reiterating that people who object to making the teaching of a language 'just a school subject' seem to misunderstand what it is that make a school subject aims to achieve [13]. Hinging on this makes it not out of place to have used souvenirs to teach punctuations. This corroborates with Okonlawon on the investigation made on T-Shirt inscriptions among undergraduate students of a Nigerian University to teach 'form and meaning' [14]. Ezirim suggests that the use of ICT should be side by side with written communication, in that, come the near future, communication, information and interpretation might be done in coded language and most likely with special formula [15]. This in a way serves as a sources of encouragement (in a way) to those who have no a faint idea of the use of ICT, can still teach and learn through creativity. The use of concrete teaching aids send an apt information into the brain through the eyes (visual perception) and ear (auditory perception); which result to positive comprehension.

\section{How Souvenirs are used in Nigeria}

Nigerians are very social people, and celebrations of events are cut across cultures. Celebrations of events like weddings, birthdays, funerals, retirements, ordinations, house warming, adoring, graduations etc, run through the year in very many communities when these happen they just not only wine and dine but also an avenue to show love, care, affluence, kindness and part of these is by giving out souvenirs to guest. The Concise Oxford Dictionary defines "souvenir as a thing that is kept as a reminder of a person, place or event".

The souvenirs are always in different items ranging from buckets, bowls, flasks, coolers, plates, hand fans, handkerchiefs, bags, notebooks, frying pans, baskets, food warmers, biros, face caps etc or any fanciful item that may seem useful for household use. They are always inscribed to depict different occasions. The content on the souvenir inscriptions is a text which contains main idea. It qualifies to be described as the main message. They contain the main intention of the giver and are always written in English.

\section{The Task}

Two Junior Secondary schools were used, Twenty student's each of the school were sampled. The students were all in (JSS1), the JSS1 class was used to ascertain how much of the English language have they acquired after spending 6 years in the primary school. They were both male and female and were between 10-12 years of age. Two weeks were used for the programme and 35 minutes was used for each contact. Three steps were considered in the plan:

Step 1: The use of text book by the teacher alone: here I used an 'Oxford English text book one' the students were asked to interrupt me to pause if they identify any form of punctuation during the reading.

Result: No Pauses. 
Assumption: Here I assumed that they were either not taught punctuation marks in the primary level or I used a wrong method.

Step 11: I made photocopies of the pages of the text book and asked the students to circle the punctuations they identified in the text.

Result: only 5 students had $10 \%$ correct, the rest nil.

Assumption: I assumed that they were not taught. I used another method.

Step 111: I asked every student to come with two each of souvenirs from home to the next class. The students inquisitively responded with 40 souvenir items. I went into actual teaching of what punctuation is. The souvenir items were used as my teaching aids (See appendix).

Result: the students at this time were able to identify the types, their functions and were able to use them in the class exercise given to them. And I recorded 90\% correct usage of punctuation marks!

\section{Conclusion}

Using the materials available to you as a teacher is the most rewarding part of the teaching profession. English language teachers in the developing countries should be effective by being resourceful, innovative through improvisation thus making use of what is available to them as this also allows their students to be involved in the activity. This is the cheapest and stress less way of teaching students by using a concrete teaching aids that are available to them.

\section{References}

[1] Barduhn, S, "Imperialism and the Role of the EFL Teacher" IATEFL, Liverpool Conference Selection (ed. Pattison), UK, 2013, pp 40-50.

[2] Faleke, V.O and Ibrahim, S "GSM Test Messages: Impediment to the English Orthography in the $21^{\text {st }}$ Century" Journal of Nigerian English Association, Nigeria, 2009, pp $51-62$

[3] Wedell, M, and The Hornby Scholars, "Becoming an Effective English Teacher" IATEFL, Liverpool Conference Selection (ed.) Pattison. T, UK, 2013, pp 22-26.

[4] Olawale, O.M, "An Investigation into the Skills Needed by Adult Learners of English for Functional Purposes", Journal of Arts and Education, vol. 5 No 1, Nigeria, 2011, pp 201-213.
[5] King, G, Good Grammar, Haper Collins Publisher, Glasgow, 2000, pp 1 - 487.

[6] Babalola, E.T, "The Grammar of Paragraphs and the Mechanics of Good Written English" Perspective in Language and Literature, Obafemi Awolowo University Press Ltd, Nigeria, 2005, pp 269 - 284.

[7] Wikipedia, (2004) 'Dutsin-Ma' http://www.Dutsinma/free... (23 May 2014).

[8] Wikipedia, (2013) 'Text Linguistics' http://www. F: Text $\% 20$ linguistics $\% 20-\%$ wikipedia,\%20free\%...(1June 2014).

[9] Ed. Gov US. Department of Education (2004) 'What is Do We Mean by "Innovation"? http://www2 .ed.gov/rschstoffices/list/about/definition:html. (23 May 2014).

[10] The Academy Foundation: Fundamentals of Literature \& Drama (2004) 'What is a Text?' http:wwwacademy/foundation/fundamentals.

[11] Crystal, D and Davy. D, The Cambridge Encyclopedia of Language. University Press, Cambridge, 1987.

[12] Goldstein, B, Working with Images, Cambridge University Press, Cambridge, 2009.

[13] Widdowson, H.G, Teaching Language as Communication Oxford University Press, Oxford, 2014.

[14] Okonlawon, B, "An Analysis of T-Shirt Inscriptions among Undergraduate Students of a Nigeria University", Papers in English and Linguistics, vol. 12, 2011, pp (1-11)

[15] Ezirim, C.D, "Communication Language in Y2K: Hieroglyphics or Words?" Journal of the Nigeria Association for Semiotics Studies vol. 3, 2012, pp 87-92. 


\section{Appendix}
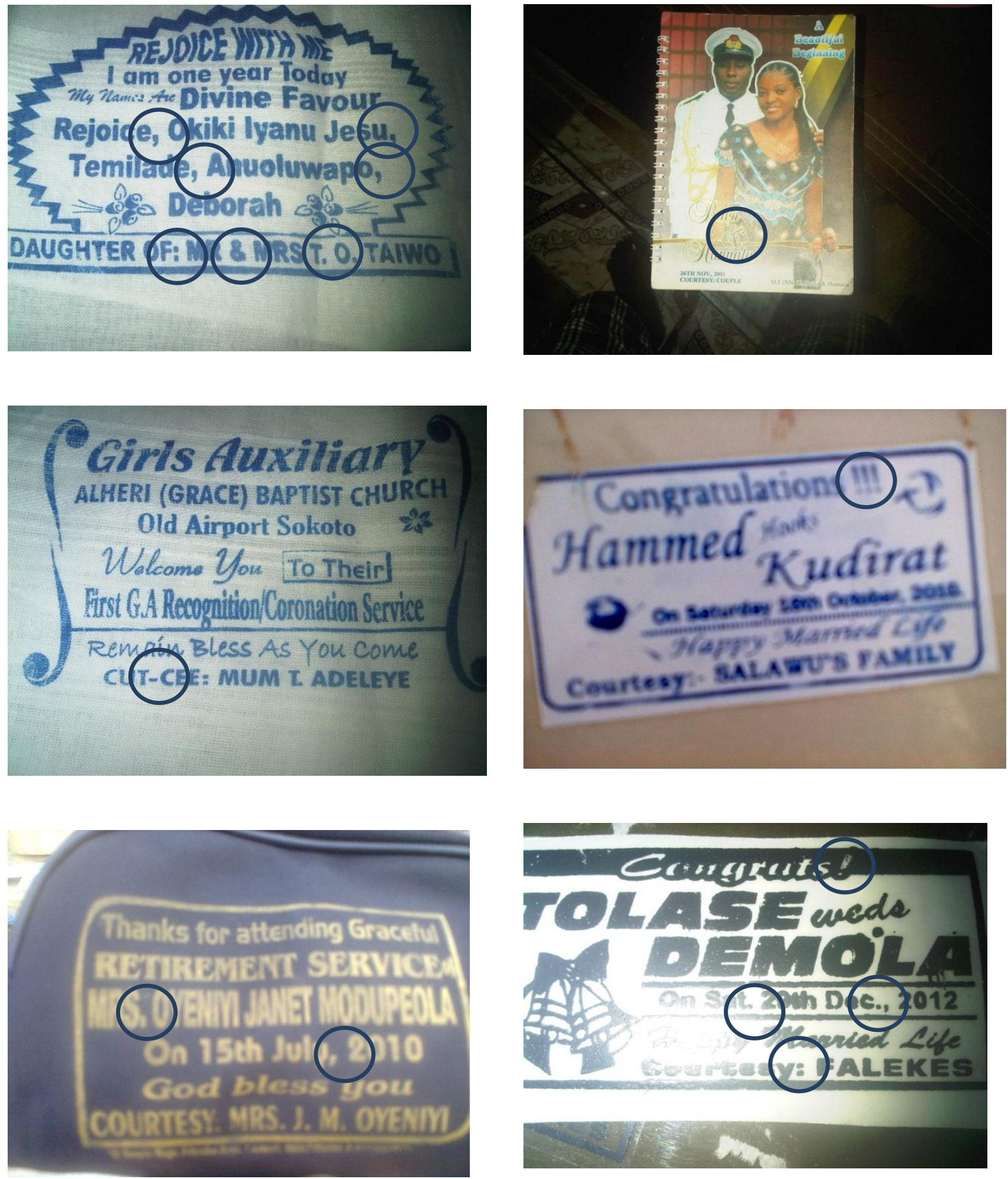